\title{
Regulating Prices in Competitive Markets
}

\author{
Roger G. Noll* and Lewis A. Rivlin**
}

In a recent article in this Journal, ${ }^{1}$ Baumol and Walton review the debate over the proper theoretical approach to setting prices for services of regulated monopolies that offer some competitive services. Their article makes two principal points: (1) Incremental cost, ${ }^{2}$ rather than fully distributed cost $^{3}$ should be used to set minimum prices in competitive markets because it results in lower prices to consumers; and (2) federal regulatory agencies are adopting this standard.

Neither of these conclusions is necessarily true. Since a regulated firm is allowed to earn the same rate of return on the same total investment, adopting incremental cost methods may lower prices in a competitive market and increase prices in a monopoly market. In addition, prices eventually will be higher if the price-setting method creates incentives for regulated firms to adopt higher cost technologies, causes the costs of dealing with regulators to increase substantially, or insulates the regulated firm from having to pay for inefficient practices through loss of markets.

A regulator faces several formidable practical problems in implementing an incremental cost method for setting prices in industries in which some of the competitors operate simultaneously in other regulated monopoly markets. A regulated monopolist can use an incremental cost standard to foreclose competition that is economically desirable. If this occurs, prices for the monopoly service, the monopolist's costs, and ultimately prices for the potentially competitive service will be higher than if competition had not been prevented. Aware of such

- Senior Fellow, The Brookings Institution, Washington, D.C. B.S., 1962, California Institute of Technology; Ph.D., 1967, Harvard University.

* B.A., 1951, Swarthmore College; J.D., 1957, Harvard University.

Dr. Noll has served as an cconomic consultant to Microwave Communications, Inc. (M.C.I.), a party contesting AT\&T theories and practices in cost analysis and ratc-making for competitive private line services. Mr. Rivlin, an attorney in Washington, D.C., serves as counsel to M.C.I. The views expressed herein do not necessarily reflect the opinions of M.C.I. or of the trustees, officers or staff of the Brookings Institution.

1. Baumol \& Walton, Full Costing, Competition and Regulatory Practice, 82 YALE L.J. 639 (1973) [hereinafter cited as Baumol \& Walton].

2. Incremental cost is the additional cost to the firm of supplying a particular service.

It excludes costs directly attributable to the production of other services and certain unattributable costs which are incurred in common for all services supplied by the firm and do not vary with the level of output.

Baumol \& Walton 639 (footnote omitted) (emphasis in original).

3. Fully distributed cost combines the additional cost to the firm of supplying a Id.

particular service with some proportion of the unattributable costs. 
potential hazards of incremental cost pricing, regulators generally have been reluctant to adopt this approach.

\section{Incremental Cost Methods and Predatory Pricing}

There is ample support for the proposition that predatory pricing in any industry, particularly by a regulated monopolist in a competitive market, is undesirable. ${ }^{4}$ Unfortunately, an incremental cost method of setting regulated prices invites predatory pricing.

In a competitive, unregulated market, firms, reluctant to incur a loss, normally will not sell a service at a price that falls below incremental cost. Such pricing usually occurs only as a short-term marketing strategy, either to drive a weaker competitor out of business, thereby creating or protecting a monopoly, or as a form of advertising to establish a market position. ' In both instances, the entire price structure must eventually generate revenues higher than incremental costs, or the strengthened market position will not be worth the costs incurred to achieve it.

In a regulated industry, a firm may benefit by a long-lerm strategy of pricing a service below its incremental cost. Permissible profits are based on some fixed fraction of either total costs or the costs of the capital investment. Thus, if a regulated firm loses part of its market to a competitor, its costs will decline and it will be permitted to earn less profit. If it operates in two markets, one competitive and one monopolistic, then it may earn more profit if it continues a belor-cost operation in its competitive market and makes up the loss by raising prices and reducing sales in its monopoly market. ${ }^{\circ}$

4. In Ovitron Corp. v. General Motors Corp., 295 F. Supp. 373, 378 (S.D.N.Y. 1969), the court said:

Pricing below cost is a severely anti-competitive tactic frequendy engaged in by corporations with significant resources to drive weaker competitors from the ficld. While the consumer may be the immediate beneficiary of the price struggle, if the tactic succeeds he will eventually be subject to the economic strength and therefore the discretionary pricing of the survivor. In the meantime, competitors will be driven out, not by the superior efficiency of the larger entity, but rather by the greater resources which enable it to sustain temporary losses for a longer time.

See National Dairy Prods. Corp. v. F.T.C., 412 F.2d 605 (7th Cir. 1969); Lloyd A. Fny Roofing Co. v. F.T.C., 371 F.2d 277 (7th Cir. 1966); National Dairy Prods. Corp. v. United States, 350 F.2d 321 (8th Cir.), remanded on other grounds, 384 U.S. 883 (1965); Allas Bldg. Prods. Co. v. Diamond Block \& Gravel Co., 269 F.2d 950 (10th Cir. 1959), cerl. denied, 363 U.S. 843 (1960); Maryland Baking Co. v. F.T.C., 243 F.2d 716 (4th Cir. 1957); E. B. Muller \& Co. v. F.T.C., 142 F.2d 511 (6th Cir. 1944); Porto Rican American Tobacco Co. v. American Tobacco Co., 30 F.2d 234 (2d Cir. 1929).

5. For example, to establish such a position a grocery chain might reduce prices on a few "loss leaders."

6. See Averch \& Johnson, The Behavior of the Firm under Regulatory Constraint, 52 AM. ECON. REv. 1053 (1962). Employing conventional microeconomic theory, the authors predict that regulated firms whose profits on fixed investments are limited to a "fair 
If it has diseconomies of scale, the regulated firm will have added incentive to price below incremental cost. Without regulation, a firm will increase output only to the point where the last unit of output generates a large enough increase in revenues to cover its incremental cost. If a regulated firm faces diseconomies of scale, this practice will normally produce greater profits than the firm is allowed to earn. ${ }^{7}$ The firm will be able to retain some of this additional profit only by increasing production beyond the point where incremental cost equals price.

Under a system of incremental cost pricing, the greater the fraction of total costs that can be put into a pot of "unallocated" costs, not included in the incremental costs of any service, the greater is the ability of the firm to alter prices to maximize its own profit. This increases the firm's ability to subvert the purpose of regulation by undercutting its competitive rivals and inching up prices in its monopoly market to the level that would prevail without regulation.

\section{Detecting Incorrect Estimates of Incremental Cost}

Because a regulated firm may find it profitable to underestimate incremental costs, adoption of an incremental cost standard for prices creates an enforcement problem for the regulatory agency. Detecting incorrect or improper estimates of incremental costs is difficult for several reasons:

\section{A. Defining Services}

The incremental cost of a particular service depends upon the concepts used to define services. Although they may have largely overlapping technical characteristics and costs, distinctions among services

rate of return" will tend to use more capital than is economically efficient. In thcir initial theoretical treatment, Averch and Johnson dealt primarily with the tendency of regulated firms to substitute capital for labor. Extending their model for a two-service firm, realistic assumptions about production technology and demand would predict that the regulated firm will also produce too much output and charge too low a price in the competitive market.

7. Assume that a firm experiences diseconomies of scale for its total output of all services. This means that the incremental cost of each service grows higher as total service increases; the sum of the incremental costs exceeds the total costs of the firm. Prices intended to recover incremental costs, including the profit allowed by regulators, would generate revenue that exceeded the total costs the firm is allowed to recover. Therefore, the firm has a strong incentive to increase its costs to capture grcater revenucs and profits. Unless the firm incurs unproductive costs, the only available mechanism for capturing additional potential profits is to reduce prices and increase output and costs. This, however, results in a situation in which prices are lower than that reculuired to recover incremental cost, and sales are expanded in the face of scalc discconomies that could be avoided through competition. 
often are made to accommodate different groups of users. For example, suppose a broad class of services $C$ includes Service $X$ and Service $Y$, and that an important component of the cost of $X$ and $Y^{\prime}$ is a joint cost $E$. If either $X$ or $Y$ is produced, some expenditure of $E$ must be made, but producing either $X$ or $Y$, once the other is produced, creates no increase in $E .^{8}$ If the firm decides to treat $X$ and $Y$ as distinct services, then the incremental costs of neither $X$ nor $Y$ will include $E$. But, if the firm decides to treat the broad class $C$ as the "service," its incremental cost will include $E$. Obviously, if a regulated firm faces competition in marketing $X$ and $Y$, it will be able to compete more effectively if it adopts the more narrow definition of services so that neither service will be required to recover $E .^{9}$

In theory, the regulatory agency could respond to this problem by performing several incremental cost analyses. It could then require that each service and the members of a class of services earn at least their incremental cost. This would require highly detailed knowledge of the technology and economics of the regulated firm, and the quantity, quality, and continuity of personnel to carry out numerous sophisticated estimates of incremental costs. This kind of information and capacity for analysis is not usually present in the regulatory agencies or the regulated firms. ${ }^{10}$

\section{B. The Choice of Technology}

Any mechanism for regulating prices creates incentives for a regulated firm to base its technical decisions on factors other than economic efficiency. ${ }^{11}$ An incremental cost standard creates an incentive to adopt

8. For example, a class of railroad services could be the totality of services offered between a pair of cities. The components of that class would be the several types of freight shipments available. $E$ would then cover the basic costs of offering any service, such as terminals and tracking.

9. In the railroad example, supra note 8 , the first method would result in a floor on the price of each type of shipment that was based on the incremental cost of offering a new service. The second method would require that prices be set so that the total revenues earned between the two cities equaled the incremental cost of offering the services between them, as compared to abandoning the route.

10. In another context, Dr. Baumol has argued that firms are unlikely to cxhibit the overcapitalization predicted by Averch and Johnson, supra note 6, because "firms have neither the extensive information nor the refincd decision process necessary to lead unerringly to the A-J [Averch-Johnson] input distortions." Baumol \& Klevorick, Input Choices and Rate-of-Return Regulation: An Overview of the Discussion, 1 Bent. Journal $189(1970)$. Yet precisely the same kind of extensive, detailed information on production and cost functions is required to calculate incremental costs. If incremental cost methods force firms to develop this information, the tendency $10.1-\mathrm{J}$ overapitalization will increase. Unless regulators have it available, prices will bear no meaningful relation to true unestimated incremental cost.

11. For a detailed treatment of the general problem of suboptimal technieal choices by regulated firms, see Technological Ciange in Regulated Industmaes (W". Capron ed. 1971). Among the examples discussed is the intriguing case of "pigg) back" railers. 
technologies that make unattributable costs as high a fraction of total costs as possible. If more costs are unattributable, the regulated firm obtains a great advantage since the incremental cost floor on its prices in the competitive market will be lower. Thus, in choosing among alternative technologies, the incentive of the firm is shifted from minimizing total costs to reducing the costs that can clearly be attributed to the competitive service, even if this results in higher total costs.

Again, theoretically, a regulatory agency could be so knowledgeable about the technical alternatives available to the regulated firms, including those specifically uninvestigated, that inefficient technical choices could be prevented. Such prescience on the part of the regulator is unlikely, particularly in an industry in which nearly all of the research and development is done by the regulated firms. Promising technical possibilities that threaten the "natural monopoly" of the firms may surreptitiously be suppressed.

\section{True Costs of Materials}

If incremental cost is to be meaningful, the prices paid by the regulated firm for the resources used to produce a service must reflect their true economic costs. If the regulated firm owns its principal suppliers, or if one supplier is the sole provider of some materials for both competitive and monopoly services, there is almost no way to insure that the regulated firm will not shift much of the true cost of the materials used in its competitive services to its monopoly services. ${ }^{12}$ To protect against this, the regulatory agency would need to become familiar with the technology and cost structure of the original suppliers. ${ }^{13}$

\section{Incremental Costs and the New Competitor}

When an efficient new entrant seeks to compete with a regulated firm, society may benefit if the established firm lowers its price in

Price regulation based on historical costs forced the railroads to adopt cxtra-long flat cars for carrying loaded trucks. These cars were expensive to build and necessitatcd regrading of some roadbeds and recutting some tunnels not designed for such long cars. Consequently the innovation of truck-rail piggyback service was much more expensive than it could have been. See Gellman, Surface Freight Transportation, in TEchNolocicnL Chance in Regulated Industries 166.

12. A different form of the problem of a vertically integrated firm arose in the early history of the airline industry. Carriers, often owned by aircraft manufacturers, purchased inferior or high-cost airplanes from their sister enterprises. As a condition of regulation and subsidization of the industry, the federal government forcel dis. solution of the vertically integrated firms. See A. PHiLlips, TECHNOLOGX AND MAKkEr STRUCTURE 74-77, 93 (1971).

13. In the case of telecommunications, as an example, the FCC would need to be satisfied that Western Electric did not underprice microwave equipment used for conl. petitive private line service and overprice telephone instruments used primarily in monopoly telephone services. 
response to the competition, and continues to provide service while its short-run incremental costs fall below the long-run incremental costs of the competitor. ${ }^{14}$ In a competitive market, the price charged by the established firms tends to produce revenues equal to long-run incremental costs. If a competitor invents a new technology with lower long-run incremental costs, prices will tend to fall until revenues for all firms are consistent with the new technology's long-run incremental costs. Firms using the old technology will continue to operate with old facilities as long as the new price permits them to cover their short-run incremental costs, but eventually, as their capital facilities wear out, they will be forced either to adopt the new technology or to leave the industry. Applying this description to a regulated market, the regulatory rules that most closely parallel competitive behavior are as follows: (l) allow the price to be determined by the long-run incremental costs of the new, efficient producer; (2) allow the higher cost producers to continue to offer service with facilities that would otherwise lie idle or that have less valuable alternative uses at a profit-maximizing price approaching that of the new competitor as long as they can cover their true short-run incremental costs; and (3) prohibit the higher cost producers from constructing new facilities unless the true long-run incremental costs of the new facilities are at least as low as those of the lowest cost producers.

In practice, those rules are difficult to implement because of the socially undesirable incentives they create for the regulated firm. If the established firm perceives that incremental cost will be the basis for pricing decisions by the regulatory agency, it may choose technologies that appear to minimize short-run incremental costs. For example, by substituting capital equipment for labor, more of the service is accounted for by capital investments that generate little or no short-run costs. The established firm could thereby maintain high sales and low profits in the competitive market, and, unless forbidden by the regulatory agency, could cover some of the long-run incremental costs of the competitive service by increasing prices in its monopoly markets.

The recent Otter Tail decision ${ }^{15}$ proscribed under $\$ 2$ of the Sherman Antitrust $\mathrm{Act}^{16}$ a number of actions to prevent municipal power

14. For the established firm, the difference between short-run and long-run incremental costs is the annualized fixed cost of the service. In the short-run the firm's capital investments are fixed; over time the amount of capital invested is variable, as are expenditures on all other productive resources. To calculate long-run costs, one assumes that no capital facilities have been built or other fixed resource commitments made, and that one is free to choose whatever technologies and combination of resources will produce lowest costs.

15. Otter Tail Power Co. v. United States, 93 S. Ct. 1022 (1973).

16. 15 U.S.C. $\$ 2$ (1970). 
companies from entering the market to serve their own communities. The effect of this decision would be subverted if the private electric utility were permitted by a regulatory authority to adopt a pricing scheme allowing it to destroy municipal power competition by selectively lowering its offered rates in areas where its licenses were up for renewal, and the communities wished to offer municipal service. This scheme would enable the power company to establish substantially lower rates, since the incremental costs of continuing service in areas previously served would be substantially lower than the incremental costs of initiating service to a particular locality.

In regulated industries "competition" is often over the right to a monopoly-two firms may bid for the right to be the sole supplier of a service. The new firm would always be excluded by application of a rule which allowed the established firm to continue to be the sole pro. ducer as long as its short-run incremental costs were lower. Only a small part of the established firm's fixed capital investments mature at a given time, so that it will always have substantial fixed costs that are excluded from the short-run cost calculation. Consequently, the established firm is not pressured by competition from the new firm to adopt lower cost methods. Therefore, although initially resulting in lower prices, this rule would not result in production at lowest cost.

\section{Current Agency Practice}

Baumol and Walton imply that the regulatory agencies are on the verge of adopting an incremental cost standard as the sole means of determining rates for regulated services. ${ }^{17}$ The agencies, however, have been cautious in applying incremental cost. ${ }^{18}$

Baumol and Walton also imply that the use of incremental cost standards represents a repudiation of a fully allocated cost standard.10 In fact, regulators rarely relate prices of individual services to iny

17. Baumol \& Walton $644,647,655$.

18. See, e.g., Federal Maritime Commission General Order 29, 37 FED. REc. 25717 (1972). The Federal Maritime Commission specifically required that fully distributed cost mcthods be used by carriers transporting military cargo. Unallocated common costs were to be handled as follows: "[W] here a carrier... operates a facility which is used jointly with another service, expense considered common to both areas shall be allocated to the military service on the basis which accurately reflects the relative use each service makes of the common facility." Id. at 25719. See also American Lines v. Louisvillc \& N.R. Co., 392 U.S. 571 (1968); Los Angeles v. Federal Maritime Commission, 385 F.2d 678, 682-83 (D.C. Cir. 1967).

Members of Congress have introduced bills to authorize private predatory pricing suits under $\S 3$ of the Robinson-Patman Act, 15 U.S.C. $\S 13(a)(1970)$. See S. 780, 98d Cong., lst Sess. (1973), and H.R. 2384, 93d Cong., 1st Sess. (1973) which would requirc that costs for such purposes be defined as "fully distributed costs."

19. Baumol \& Walton $639,644,655$. 
measure of costs. The issue before an agency usually is not which cost method to adopt, but whether the agency should continue to favor a price structure in which the rates for some services are below any measure of costs. ${ }^{20}$ For example, the CAB pursued a "cross-subsidy" policy, setting prices below costs on certain low-density air routes and making up the losses by monopoly pricing on more lucrative routes, in order to maximize the number of cities provided with air service."1 Since most of the low-density routes are monopolies, and most of the profitable routes are to some degree competitive, the issue at the CAB was whether to raise prices on monopoly routes to at least incremental cost levels. The $\mathrm{CAB}$ eventually abandoned cross-subsidization and adopted cost-related pricing because the firms simply eroded away monopoly profits by engaging in nonprice competition on their profitable routes.

Similarly, the debate over route abandonments at the ICC has focused on whether a firm should be forced to continue serving a monopoly route when its revenues are not adequate to cover incremental costs. The ICC's basic policy on rates for individual commodities has been to maintain rate differentials between low-value bulk commodities and high-value manufactured commodities through valueof-service pricing. ${ }^{22}$ The specific issue is whether to move in the direction of cost-based rates-any method of cost-based rates-rather than engage in the continued subsidization of bulk commodity shipments by other types of shipments. ${ }^{23}$

\section{Recommended Agency Direction}

By revising their policies on allowable costs, the agencies could remove some of a firm's incentive to provide uneconomic service in competitive markets. One necessary step is to prevent the use of higher prices in the monopoly markets to recapture the difference between

20. For a more complete discussion of the attitude of regulatory ageneies towards prices and new technology, see R. Nolx, Reforming Reglition: AN Evaluation of the Ash Council Proposals 15-32 (1971).

21. See G. EAds, The Local Service Airdine ENPERIMEIT (1972).

22. A. Friedlander, The Dilearai of Freigit Transiont Regulition 27 (1969).

23. One economist has assessed cost-based rates at the ICC as follows:

The application of cost-based rates as defined by an cconomist would tend to create an incorrect specification of costs, incorrect adjustuments in capacity, and cxcessive losses. But cost-based rates as defined by the ICC have definitcly created misspecification of the costs and thus led to misspecification of the rate floors. Basically, the problem lies with a rather mechanistic and simplistic attempt to estimate some subtle cost relationships... . Thus until the techniques and skills used in rail costing improve considerably; tying rates to costs should be avoided. The probable errors of estimation are so great that the losses involved with the application of misspecified rates may be greater than the losses associated with the forms of price discrimination currently practiced. Id. at 137 . 
the revenues earned in the competitive market and the costs of all the resources used in providing the competitive services. This would remove the incentive for the regulated firm with some monopoly markets to persist indefinitely in serving a competitive market at a price that did not allow it to recover all of its costs.

While incremental cost analysis could potentially provide useful information to regulatory agencies, a substantial period of time will be necessary to refine the techniques and train regulatory personnel to be alert to the many potential abuses. Until then, the agencies may find useful the presentation of supplementary long-range incremental cost data and other attempted justifications of lower rates in competitive areas, but greater reliance should be placed on fully allocated cost studies of the regulated firms. Such studies would provide more complete information as to the extent of subsidization of competitive services by monopoly services. 


\section{The Yale Law Journal}

Volume 82, Number 7, June 1973

\section{RICHARD BLUMENTHAL Editor-in-Chief}

Gurt Hessler

ROBERT B. REICH

Charles L. WoltalanN

Article Editors
ROGER W. FONSECA Charles A. Goldmark HenRy B. HansaranN Daniel J. KorNSTEIN Jay E. Powell

Note \& Comment Editors

Carl E. ANDURI, JR. RALPH R. ARDIII Alan E. Boles, JR. JOHN R. BoLTON Michael J. BEAN RoY L. Brooks Dominic J. CaMrpisi Colemin H. Casex Mrchael J. Churgin Michael M. Conway Christopher G. CURTIS KATHLEEN M. DOGgETT Peter H. Ehrenberg ROBERT W. FISHER DONALD J. FrIEDMaN JaMes N. Gardner NANCY C. GARRISON RoBert T. GILLERAN Frederick Goldberg, JR. John S. Graham III Steven R. Gross
M. Martha HartLe Frederick Heller, Jr. Peter M. HoffMan STEPHEN T. Holzer REed E. HundT RaNDALL K.C. KaU Richard C. LINQUANTI EUGENE A. LudWig JaMies T. Malysiak Robert B. ManN Kathleen P. Margh David A. Martin S. HARDWICKE MAYS, JR. Charles Mulaney, Jr. NeIL H. O'DonNelt Russell K. OsGOOD Samuel T. Perkins William J. Perlstein John H. Peters Williak R. Phelps
Peter T. Grossi, Jr. Executive Editor
Robert E. GirsoN Managing Edilor NANCY Y. BEkAYAC Bool Reviews Edilor
LINDA L. RANDELL DAvid B. ROE Gerald Rokoff Stewart G. Rosendzuar Peter L. Rossiter Michael L. Sahler JAN SCHNEIDER Donald E. SCOTT LESLiE N. SilverMIAN ARThur J. SilversteIN GARY J. SimSON Peter TW. SLY Robert MI. SMIth James R. Saroot MARK I. SOLER ROBERT M. SUSSMCAN TIMOTHY P. TERRELI. S. MARK TULIER FrANK G. WASHINGTON MARK L. WEISSLER JOAN G. WEXLER

Business Sectetaties M. Orive Butterfield, Pamela Willnotr

\section{Student Contributors to This Issue}

Jerome C. Hafter and Peter M. Hoffman, Segregation Academies and State Action

David B. Roe, Privacy in the First Amendment

Michael M. Conway and Dennis R. Honabach, The Unconstitutional Burden of Article 15

John R. Bolton and Stephen T. Holzer, Legal Services and Landlord-

Tenant Litigation: A Critical Analysis

William J. Perlstein, Revising the Private Placement Exemption Joan G. Wexler, The Equal Rights Amendment and the Military 